\title{
An Assessment of Wakkerstroom Wetland and Its Vegetation Communities from 1938 to 2019
}

\author{
Victoria Alma Stockdale, David Gordon Furniss, Mary Catherine Scholes \\ School of Animal, Plant and Environmental Sciences, University of the Witwatersrand, Johannesburg, South Africa \\ Email: vstockdale@gmail.com
}

How to cite this paper: Stockdale, V.A., Furniss, D.G. and Scholes, M.C. (2021) An Assessment of Wakkerstroom Wetland and Its Vegetation Communities from 1938 to 2019. Journal of Water Resource and Protection, 13, 807-821.

https://doi.org/10.4236/jwarp.2021.1310043

Received: September 28, 2021

Accepted: October 26, 2021

Published: October 29, 2021

Copyright $\odot 2021$ by author(s) and Scientific Research Publishing Inc. This work is licensed under the Creative Commons Attribution International License (CC BY 4.0).

http://creativecommons.org/licenses/by/4.0/

\begin{abstract}
There are few studies on the size and changes in species composition over time for wetlands in South Africa. Techniques such as remote sensing have become popular in assisting the development of management plans due to their spatio-temporal advantages and easily reproducible vegetation and land cover maps. The Wakkerstroom wetland was examined using aerial photography to examine possible changes in the extent and Landsat imaging was used to map its vegetation communities. To assess the distribution of vegetation types on Wakkerstroom wetland, in situ recording of vegetation types and their GPS coordinates was conducted and a Random Forest model was used to predict vegetation types from Landsat pixel spectra across the wetland extent. As calculated from aerial photographs, the Wakkerstroom wetland has increased in extent by $0.483 \mathrm{~km}^{2}$ from 1938 to 2009 . The $P$. australis population density increased significantly over time $(\mathrm{r}=0.89)$, whereas the $T$. capensis population density had a strong negative correlation over time $(\mathrm{r}=$ -0.70). A strong negative relationship between $P$. australis and $T$. capensis existed $(\mathrm{r}=-0.88)$. A need exists to introduce a management tool that will create a greater mosaic of vegetation communities thus ensuring a greater bird, reptile, and amphibian diversity.
\end{abstract}

\section{Keywords}

Phragmites australis, Random Forest, Remote Sensing, Typha capensis, Wakkerstroom Wetland

\section{Introduction}

Several studies have suggested that wetlands are the most threatened ecosystems globally. Approximately $50 \%$ of all wetlands have either been degraded or destroyed globally due to the value of wetlands' resources [1] [2] [3]. Most wet- 
lands are positioned near water courses-potentially providing economic benefits for grazing, agriculture, and forestry sectors. These economic benefits have historically resulted in many wetlands being drained for cattle grazing pastures, crop agriculture and afforestation. The transformation of wetlands to other land uses can result in crop monocultures or afforestation which reduces flora and fauna biodiversity, increases soil erosion potential, and decreases soil organic matter. Overgrazing and too-frequent burning of wetland causes decreased biomass, increased runoff and soil erosion resulting in the formation of gullies [4].

Wetland ecosystems are critically important as they perform a range of ecosystem services. These ecosystem services include water purification, groundwater recharge, habitat provision for numerous flora and fauna, water storage and flood attenuation. Wetland ecosystem services are primarily due to vegetation structure and its dense rooting network which is commonly dominated by Phragmites australis (Cav. Steud) and Typha capensis (Rohrb. N. E. Br.) [5] [6] [7] [8] [9]. Studies have voiced concern about the hyper competitiveness of $P$. australis which has achieved invasive weed status in several countries, including North America where huge monospecific swathes have outcompeted the native vegetation and have thus diminished biodiversity [10] [11] [12] [13]. Wetlands, due to their heterogeneous vegetation and landscape provide habitat for a highly diverse array of bird and invertebrate species [14]. Flood attenuation and water purification are key services provided by the Wakkerstroom wetland for users downstream. Grazing for cattle is supplemented by wetland vegetation especially in drier months where another grazing is inadequate or insufficient [15].

The need to conserve and manage remaining wetlands and the crucial ecosystem services they provide are essential for human wellbeing. Hall [16] proposed that it is not enough only to conserve the populations of plants and animals exploited by anthropogenic activities but that their health and sustainability depends on conserving all biodiversity included in the wetland. Bond [17] states that although climate sets the limit to all terrestrial and aquatic vegetation growth; fire and herbivory determines the pattern of vegetation distribution. A fire regime can be described as the combination of frequency, season, intensity and type of fire that occurs in an area. A fire regime results from a sequence of individual fire events. The response of ecosystems to fire depends on both the effects of that single fire and the behaviour inherited from previous fires [18]. Burning of wetlands has numerous potential positive consequences [15], which includes the maintenance of native fauna and flora; assisting in alien plant control; removing plant litter and improving grazing value. However, negative consequences exist too, susceptible animal species could asphyxiate or succumb to the direct effects of heat, very regular fires can increase rates of erosion (especially on heavily grazed wetlands), increased evaporation from the wetland combined with a decrease in organic matter as well as an increase in ash content in the soil affects productivity. $P$. australis can be considered a wetland management problem due to its rapidly colonising and dominating behaviours in disturbed soils 
which compromises wetland biodiversity [19]. Kotze [20] found that when it was desirable to reduce the abundance of the dominant plant species to enhance habitat diversity both fire and herbicide were necessary. Unfortunately, successful conversion of dominated wetlands using only chemical control requires a diverse soil seed bank in addition to a nearby source of seeds for natural recruitment. Areas that do not possess these seed sources may need manual planting to speed up site recovery. Therefore, fire regimes and herbicide utilisation to increase plant diversity without harming the wetland are very site and species specific. Ailstock et al. [19] found that single herbicide application or herbicide application followed by burning can reduce the abundance of $P$. australis acutely in wetlands. Long term diversity maintenance required occasional herbicide applications to prevent regrowth of $P$. australis.

The Wakkerstroom wetland is classified as a national heritage site, but a proposed water extraction project upstream could potentially disrupt the vegetation structure and distribution. Creating a historical record of the wetland's vegetation structure and distribution would support the design of a database whereby comparisons and projections could be made about the wetland health. This research aims to examine the changes in wetland extent between 1938 and 2009 and vegetation distribution in the Wakkerstroom wetland from 1997 to 2019.

\section{Methodology}

\subsection{Study Site}

Wakkerstroom is in the southeast of Mpumalanga along the northern edge of Kwa-Zulu Natal $\left(27^{\circ} 22^{\prime} \mathrm{S} ; 30^{\circ} 07^{\prime} \mathrm{E}\right)$ with grasslands making up over $65 \%$ of the province [21]. The mean annual precipitation (MAP) of Wakkerstroom is approximately $914.1 \mathrm{~mm}$ and the annual potential evapotranspiration (PET) is approximately $1715.2 \mathrm{~mm}$-nearly double the MAP (PET:MAP $=1.88)$. The Wakkerstroom wetland is situated to the Northwest of Wakkerstroom (Figure 1) and is part of the Tugela River upper catchment. The main water input is the Wakkerstroom River with the remaining water coming in from smaller tributaries on the hills surrounding the area. Water leaves the wetland south of the R543 forms the Thaka River which flows into the Zaaihoek Dam [6]. The wetland has an extensive sedge marsh belt containing Typha capensis which grades into sedge meadow (plants of the Cyperaceae family). The permanently flooded interior is covered by wet grassland-dominated by Phragmites australis [22].

\subsection{Data Collection}

\subsubsection{Site Sampling}

Sampling sites representative of the different classes to be mapped were selected with the vegetation types of interest being $P$. australis, T. capensis and patches of open water (Figure 2). Sampling points were chosen around the wetland at patches of homogenous vegetation that looked to extend more than $30 \times 30 \mathrm{~m}$. Sampling points were chosen at least $60 \mathrm{~m}$ from one another. The size of vegetation 


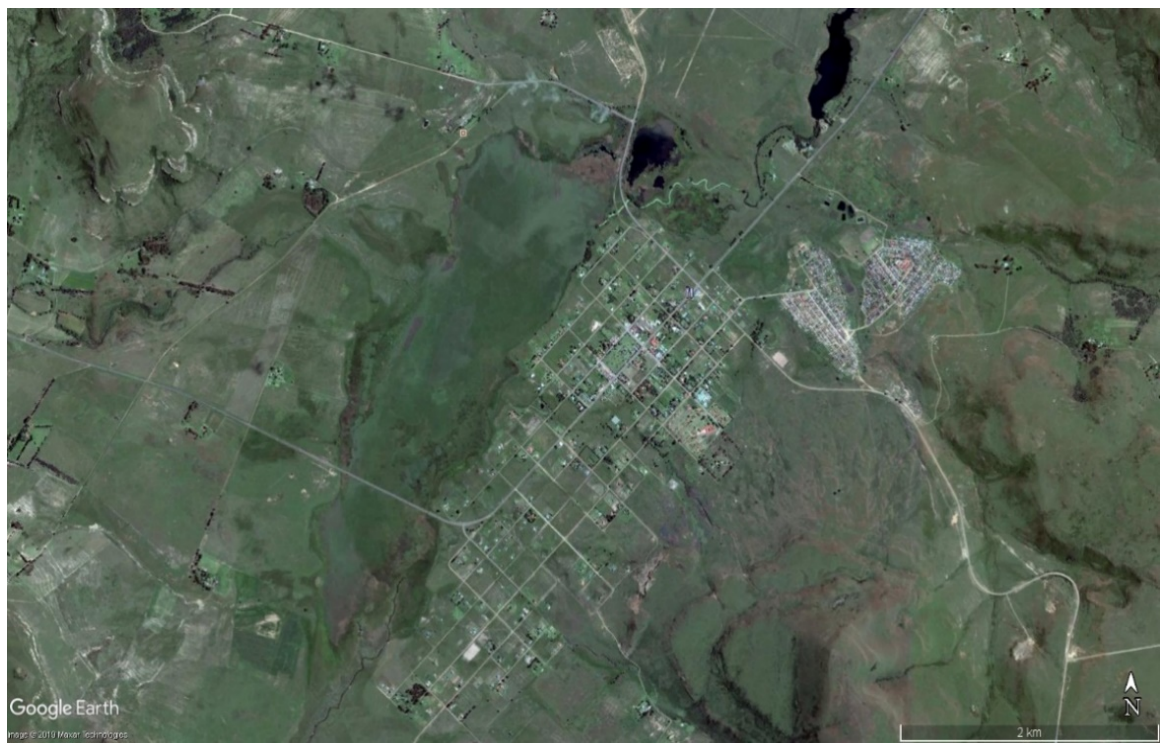

Figure 1. Google Earth image of the town of Wakkerstroom, Mpumalanga with Wakkerstroom wetland to the northwest of the town.

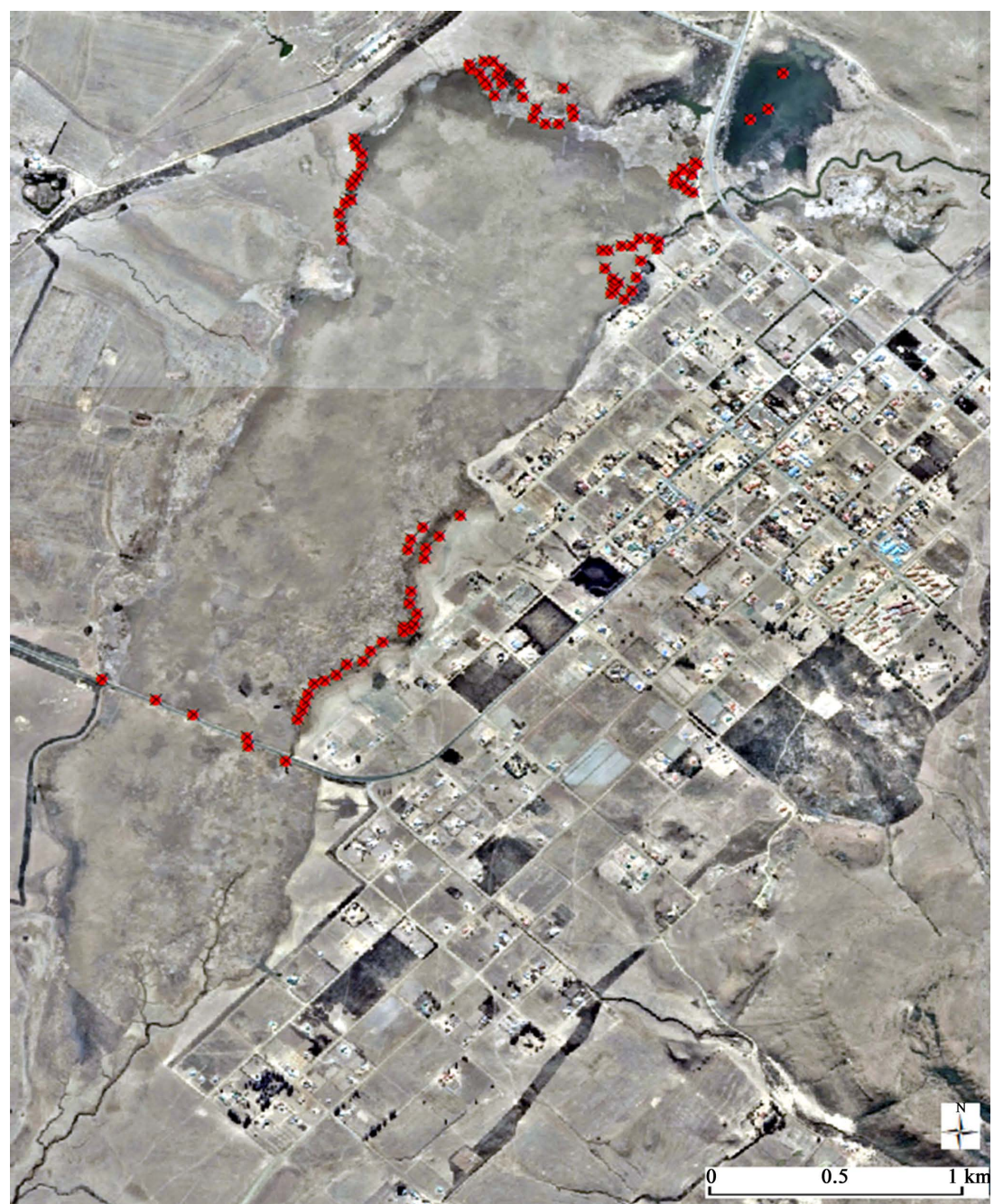

Figure 2. Map of sampling points overlain a 2009 orthophoto. 
patches and distances between points were chosen to avoid as best as possible repeat sampling within the same $30 \times 30 \mathrm{~m}$ pixel of the Landsat image did not occur.

\subsubsection{Remote Sensing Data Collection}

To determine if the boundary of Wakkerstroom wetland has changed over time aerial photographs collected in 1938, 1953, 1969, 1979 and an orthophoto in 2009 were studied. The aerial photographs were georeferenced using ArcMap 10.4 to WGS 1984 Transverse Mercator projection using the 2009 orthophoto supplied by the Surveyor General of South Africa as a base map. The wetland boundary for each year was determined as the distinctive visual border that separated wetland vegetation from surrounding grassland. The true boundary is difficult to calculate precisely as the aerial images have a low resolution and variable quality especially those taken in 1938. A polygon of the boundary was created around the outside edge of the aerial photographs' vegetative visual border in ArcMap 10.4. Using these polygons, the area inside each boundary was calculated.

Satellite data were gathered from Landsat 5 Thematic Mapper (TM) and Landsat 8 Operational Land Imager (OLI) satellites. Two images from Landsat 5 (1997/02/11 and 2005/02/17) and two images from Landsat 8 (2013/04/28 and $2019 / 02 / 24$ ) were used in the modelling process to determine vegetation community distribution. Two different satellites were used so that a longer period of images was available. Landsat 5 was launched in 1984 and decommissioned in 2013, and Landsat 8 was launched in 2013 and is still active. The Landsat TM 5 has seven spectral bands in the visible, infrared, and thermal portions of the electromagnetic spectrum. Landsat 8 OLI has eleven spectral bands in the visible, infrared, and thermal portions and a panchromatic band of the electromagnetic spectrum. All Landsat 5 bands were used, except band 6, the thermal band, for spectral extraction and modelling purposes. Bands $1-7$ of Landsat 8 were used for spectral extraction and modelling.

\subsubsection{Modelling}

The Landsat images were the spectral data sources used for the classification modelling and prediction mapping. The GPS points were used to match spectra from the Landsat images to their respective vegetation type using $\mathrm{R}$ [23] and the raster package. The spectra and associated vegetation classes were combined into a data frame for analysis. Random Forest was used to create models to predict vegetation classes across the entire wetland [24]. First, a training model was built using $70 \%$ of the total data by means of the bootstrap resampling method and the other $30 \%$ to validate and choose the best model for prediction mapping. After the best training model was created two types of models were built. The first model was built on the assumption that for each image the vegetation type at those GPS points would remain the same as 2019 in situ classification. The second model was built on the assumption that the spectral signature of each 
vegetation type would remain the same as the 2019 classification. Neither of these assumptions is strictly accurate in a natural environment but using images at similar times of year the assumption was that the reflectance value as a product of photosynthetic action of each vegetation community would be similar and therefore adequate for modelling purposes.

Rasters of the wetland vegetation for each Landsat image were created from the predicted values generated in the Random Forest model. The percentage of land cover of each vegetation type was calculated from the number of pixels of that vegetation type as a proportion of all pixels on the wetland.

\subsubsection{Analyses}

Changes in vegetation structure and distribution were analysed using Pearson correlations. Correlations were performed between vegetation classes over time and the effect of one vegetation class on another.

\section{Results}

\subsection{Determining a Change in Extent of Wetland}

To determine if the boundary of the Wakkerstroom wetland has changed over time, the wetland was studied from several aerial photographs that were collected in 1938, 1953, 1969, 1979 and an orthophoto from 2009 (Figure 3). The boundary for each year was determined as the distinctive visual border that separated wetland vegetation from surrounding grassland. Figure 4 suggests that the boundary of the wetland is relatively dynamic. Each image illustrates that while a general shape of the wetland exists, the edges of the wetland shift noticeably over time.

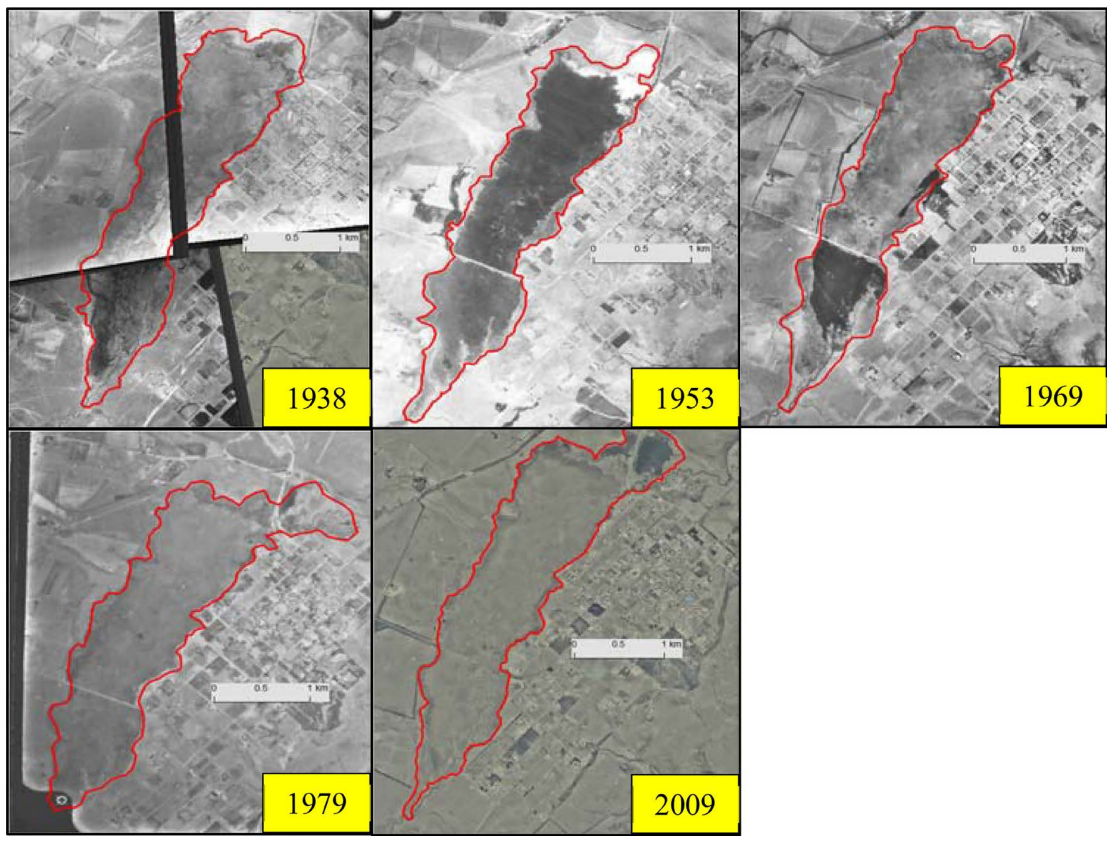

Figure 3. Aerial images of Wakkerstroom wetland for 1938, 1953, 1969, 1979 and 2009 with border outlined in red. 


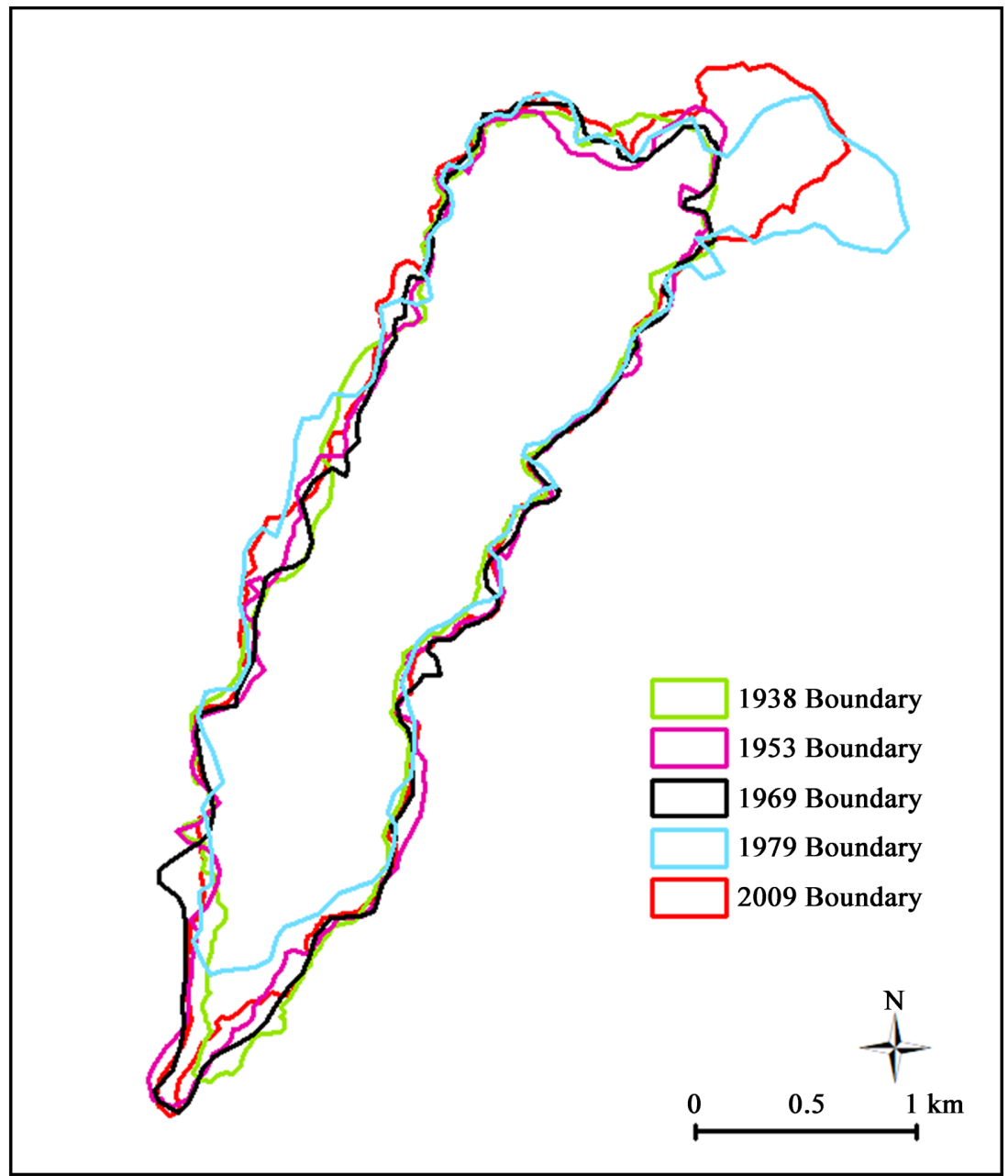

Figure 4. Overlays depicting the Wakkerstroom wetland boundaries created from aerial photographs for years 1938, 1953, 1969, 1979 and 2009.

The boundary in 1979 was the first visual appearance of open water east of the Paul Kruger Bridge. The construction of the causeway across the wetland over which the Amersfoort Road passes led to the wetland damming and creating the open water area seen in 1979 (personal correspondence, 2019).

The area inside each boundary was calculated and plotted in Figure 5. The largest increase in wetland area occurred between 1969 and 1979 with the expansion of the wetland east of the Paul Kruger bridge. The area increased by $0.243 \mathrm{~km}^{2}$ whereas the area increases between 1938 to 1953,1953 to 1969 and 1979 to 2009 was $0.085 \mathrm{~km}^{2}, 0.068 \mathrm{~km}^{2}$ and $0.087 \mathrm{~km}^{2}$ respectively.

\subsection{Creating a Random Forest Model for Vegetation Classifications}

The in situ vegetation recorded at the GPS points were used to construct Random Forest models with the respective spectra from the Landsat images. Two approaches to Random Forest models were tested. The first model was built on the assumption that for each image the vegetation type at those GPS points would remain the same as 2019 in situ classification. The second type of 
model was built on the assumption that the spectral signature of each vegetation type would remain the same. A model was derived for the 2019 image and then applied to prior years. Neither of these assumptions is strictly accurate in a natural environment but using images at similar times of year the supposition was that the reflectance value as a product of photosynthetic action of each vegetation community would be similar and therefore adequate to be used for modelling purposes. The second type of modelling using the reflectance of each vegetation community created models with the same error rates and modelling values as the first model and so model one was used hereafter (Table 1).

Each model was trained with $70 \%$ of the total data. As the model was calibrated, each decision tree component of the random forest model was tested by the samples not used in building that tree. This is known as the out of bag error estimate as it is an internal error estimate of a random forest model as it is being constructed. The final models were tested with the remaining $30 \%$ of the

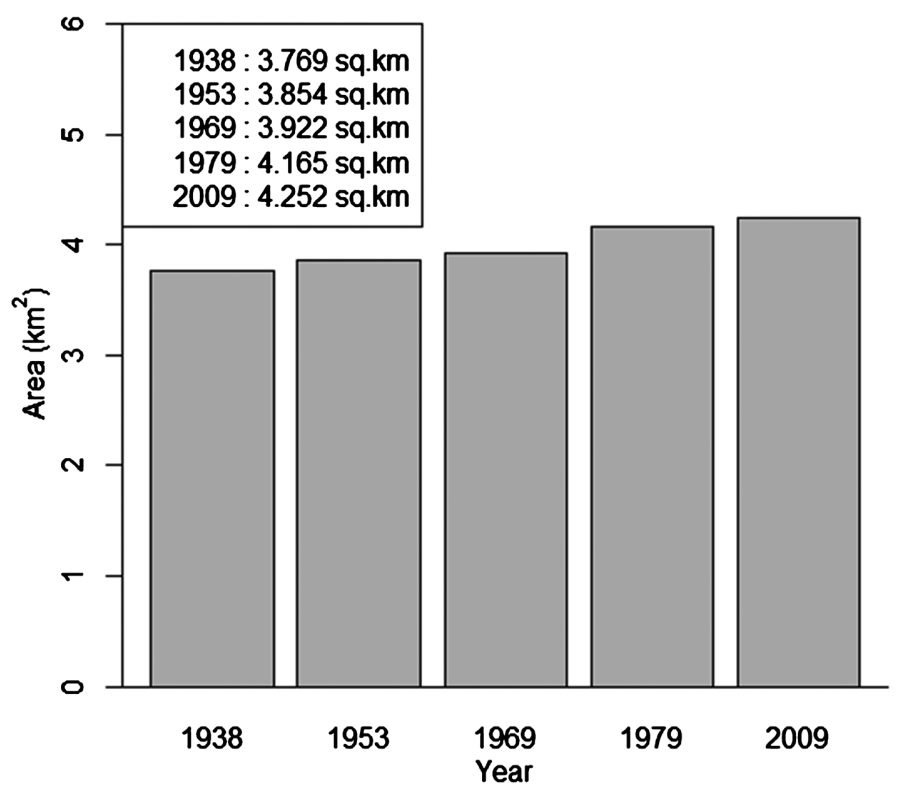

Figure 5. Plot depicting the area of Wakkerstroom wetland for years 1938, 1953, 1969, 1979 and 2009.

Table 1. Number of pixels attributed to each vegetation class of a Landsat 8 image (24/02/2019) using random forest derived Model 1 and Model 2.

\begin{tabular}{|c|c|c|c|c|}
\hline & \multicolumn{2}{|r|}{ Model 1} & \multicolumn{2}{|r|}{ Model 2} \\
\hline & Pixel Count & $\begin{array}{c}\text { Percentage of } \\
\text { wetland covered }(\%)\end{array}$ & Pixel Count & $\begin{array}{c}\text { Percentage of } \\
\text { wetland covered (\%) }\end{array}$ \\
\hline Grass & 594 & 12.5 & 595 & 12.6 \\
\hline Open Water & & 0 & & 0 \\
\hline P. australis & 1283 & 27.1 & 1284 & 27.1 \\
\hline P. australis/T. capensis mix & 580 & 12.2 & 580 & 12.2 \\
\hline T. capensis & 2278 & 48.1 & 2276 & 48.1 \\
\hline
\end{tabular}


data to validate and select the best model for prediction and mapping purposes. The model calculated $100 \%$ accuracy for the classifications produced using the calibration data with no misclassifications. Using the 1997 image, a $27.5 \%$ out of bag error estimate was calculated when classifying the validation data points. Class error (Table 2) represents the likelihood of misclassification and so a higher percentage result correlates to a higher likelihood of misclassifying the vegetation classification. Table 2 illustrates that the model had the most difficulty classifying grass ( $42.9 \%$ classification error) and $P$. australis $(58.8 \%$ classification error). The validation model predicted a $70 \%$ total accuracy when using the out of bag data points to create a vegetation classification and so $70 \%$ of the time a data point will be classified correctly to its in situ classification.

Table 3 shows the calibration model created for a Landsat 8 image dated 24/02/2019. An out of bag error estimate of $42 \%$ was calculated for the $2019 \mathrm{im}$ age when classifying the validation data points. In addition to the estimated error rate, the model had a 53\% accuracy value when using the validation data to predict vegetation classes from Landsat spectra when compared to in situ classification. Therefore $53 \%$ of the time a data point will be classified correctly to its in situ classification.

Similarly in Table 2, the 1997 classification model struggles to classify grass (57.1\% likelihood of misclassification) and $P$. australis (70.6\% likelihood of misclassification) but additionally, this model struggles to classify $P$. australis/T. capensis mix (60\% likelihood of misclassification).

This study used six reflectance bands from Landsat 5 for modelling and

Table 2. The likelihood of misclassifying vegetation types on Wakkerstroom wetland using validation model 1 created from a Landsat 5 image dated 11/02/1997.

\begin{tabular}{ccccccc}
\hline Misclassification likelihoods & Grass & $\begin{array}{c}\text { Open } \\
\text { water }\end{array}$ & $\boldsymbol{P}$. australis & $\begin{array}{c}\text { P. australis/ } \\
\text { T. capensis mix }\end{array}$ & $T$. capensis $\begin{array}{c}\text { Class error } \\
\text { (\%) }\end{array}$ \\
\hline Grass & 4 & 0 & 0 & 0 & 3 & 42.9 \\
Open Water & 0 & 3 & 0 & 0 & 0 & 0 \\
P. australis & 0 & 0 & 7 & 3 & 7 & 58.8 \\
P. australis/T. capensis mix & 0 & 0 & 0 & 9 & 1 & 10 \\
T.capensis & 1 & 0 & 3 & 1 & 27 & 15.6 \\
\hline
\end{tabular}

Table 3. Table of the misclassification likelihood between vegetation types on Wakkerstroom wetland using the validation model created from a Landsat 8 image dated 24/02/2019.

\begin{tabular}{ccccccc}
\hline $\begin{array}{c}\text { Misclassification } \\
\text { likelihoods }\end{array}$ & Grass $\begin{array}{c}\text { Open } \\
\text { water }\end{array}$ & $P$. australis & $\begin{array}{c}P \text {. australis/ } \\
\text { T. capensis mix }\end{array}$ & T. capensis $\begin{array}{c}\text { Class error } \\
\text { (\%) }\end{array}$ \\
\hline Grass & 3 & 0 & 0 & 0 & 4 & 57.1 \\
Open Water & 0 & 3 & 0 & 0 & 0 & 0 \\
P. australis & 0 & 0 & 5 & 4 & 8 & 70.6 \\
P. australis/T. capensis mix & 0 & 0 & 4 & 4 & 2 & 60 \\
T. capensis & 1 & 0 & 5 & 1 & 25 & 21.9 \\
\hline
\end{tabular}


prediction purposes. Peak reflectance for each vegetation type's spectral reflectance derived from Landsat 5 occurred at bands 4, 5 and 7 (Figure 6). These bands represent the red $(0.76-0.90 \mu \mathrm{m})$ and shortwave infrared 1 and 2 bands (1.55 - 1.75 and $2.08-2.35 \mu \mathrm{m}$, respectively). Nine reflectance bands from Landsat 8 were used in the modelling and prediction mapping. Peak reflectance for each vegetation type's mean spectral reflectance derived from Landsat 8 occurred at bands of 4, 5 and 6 (Figure 6). These bands represent the red (0.64 $0.67 \mu \mathrm{m})$, near infrared $(0.85-0.88 \mu \mathrm{m})$ and shortwave infrared band (1.57 $1.65 \mu \mathrm{m})$. Infrared bands are most reflected by photosynthetic vegetation due to the moist cell walls and airspace between cell walls. Vegetation absorbs blue and red light to power photosynthesis. Plants with higher chlorophyll concentrations absorb more red light than less photosynthetically active vegetation. Each of the vegetation communities had overlapping spectral signatures and this is a partial
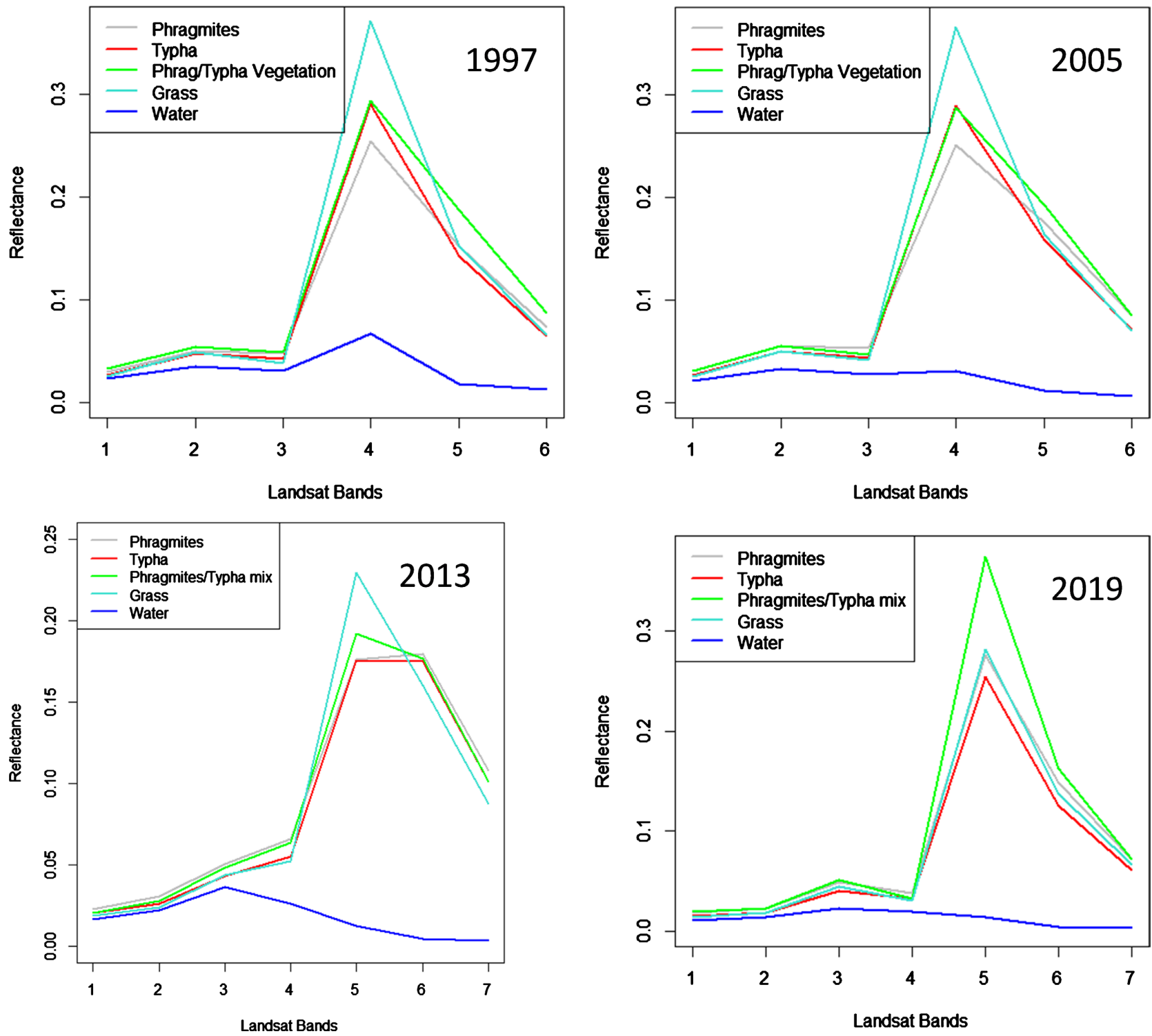

Figure 6. Reflectance values for vegetation communities within the Wakkerstroom wetland for 1997, 2005, 2013 and 2019. 
explanation as to why the model struggles to create classifications with high accuracy values and clear differentiations between vegetation types.

Once the strongest model was found after testing it against in situ data-a classification model for the entire wetland for each year was generated. Two meaningful trends are worth noting. The first is the steady increase of $P$. australis distribution on the wetland: in 1997 it represented $16.3 \%$ of the wetland and by 2019 it represented $29.7 \%$ of all vegetation types on the wetland however this increase was not statistically significant $(r=0.89, p=0.11$, Table 4).

\section{Discussion}

\subsection{Examining the Change in Wetland Extent Using Aerial Photographs}

Tuominen and Pekkarinen [25] discussed how aerial photography has assisted in vegetation and landscape mapping since the 1930s. Aerial photographs provide a general "big picture" view of landscapes and the surrounding terrain that can be used to delineate site boundaries including wetland borders [26]. The use of aerial photographs from 1938, 1953, 1969, 1979 and 2009 revealed that Wakkerstroom wetland has a non-static boundary, and its extent shifts irregularly over time due possibly to changing climatic conditions. However, since wetlands are transitional zones between aquatic and terrestrial ecosystems, wetland borders are commonly indistinct to other land classes [27] [28]. Civco, Kennard and Lefor [29] identified the subjectivity of border placement, even by experienced photo interpreters, over 40 years ago. Their observation was illustrated by the variability in boundary creation by individual experts and so composite agreement maps had to be produced by photo interpreters. The low frequency of aerial data acquisition and high variability of wetland hydrodynamics hindered accurate boundary formation especially if images were collected in different seasons.

A consideration put forward by Davis and Wang [30] is that each image should be geo-referenced to the same base map using the same reference coordinate

Table 4. Pearson correlation values used to determine the relationships between vegetation over time.

\begin{tabular}{ccc}
\hline Vegetation over time & Correlation value (r) & p-value \\
\hline T. capensis & 0.70 & 0.30 \\
P. australis & 0.89 & 0.11 \\
P. australis/T. capensis mix & 0.92 & 0.07 \\
Open water & 0.60 & 0.93 \\
Grass & 0.71 & 0.29 \\
\hline Effect of vegetation types on one another & Correlation value (r) & p-value \\
\hline P. australis and $T$. capensis & 0.88 & 0.12 \\
P. australis/T. capensis mix and $P$. australis T. capensis mix and $T$. capensis & 0.68 & 0.32 \\
\hline
\end{tabular}


system to ensure that applicable comparisons can be produced. Orthophotos are aerial images that have been geo-referenced and corrected for sensor perspective and topography and are commonly used as base maps. In this study, the 2009 aerial image had been orthorectified by the Survey General's office of South Africa and provided the base map to register the aerial images for 1938, 1953, 1969 and 1979.

The development of the open water area east of the Paul Kruger Bridge, which is likely due to the building of the causeway in 1979, is a distinctively visual example of human induced change to the wetland extent. The continual increase in wetland extent from 1938 to 2009 could possibly be attributed to the competitive and rapid growth pattern of $P$. australis [9]. The dense rooting network created by homogenous stands of $P$. australis slows water flow velocity, increases diffuse flow across the wetland and encourages sediment deposition which prolongs periods of flooding. These conditions may possibly have led to an increase in lateral extension of the wetland.

\subsection{Mapping and Quantifying the Distribution of Each Vegetation Type Using Remote Sensing}

To gather the longest historical record of data, images from both Landsat 5 (TM) and Landsat 8 (OLI) satellites were used. Both satellites have the same image spatial resolution and although these satellites have different spectral resolutions, the presence of infrared sensors on each satellite allowed vegetation identification possible. Supervised classifications can be used to classify vegetation classes automatically using computer algorithms to determine the probability that a pixel belongs to a certain class. One such method is Random Forest which is a non-parametric extension of decision tree modelling where unclassified vegetation classes can be categorised using in situ training samples [24]. The results of the random forest modelling demonstrated that with each Landsat image the predicted vegetation communities changed, most noticeably $P$. australis density increased and T. capensis density decreased. Various studies have used satellite imaging with some success [31] [32] [33] whereas others have found that the technology is inadequate to map vegetation in smaller areas [34] [35]. The aim to map the distribution of vegetation types present on the wetland did not provide significant results that demonstrated the model could classify vegetation with a high level of certainty but these results did allow for an improved understanding of wetland vegetation dynamics. Factors that might be responsible for these results could include the spatial and spectral resolution of the data interpreted from each satellite. Repeating the modelling using other satellites that have a finer spectral or spatial resolution might be useful for this type of study. Photosynthetic vegetation which contains chlorophyll $\mathrm{a}$ and $\mathrm{b}$ tend to absorb light of the wavelengths $\sim 400-700 \mathrm{~nm}$ and has a much higher reflectance in the near infrared region between $\sim 700-1400 \mathrm{~nm}$. The results showed that the spectral reflectance using the Landsat narrow bands for each vegetation type was very similar and contained no discernible contrast with which to make distinc- 
tive classifications. This could be attributed to the vegetation types having similar concentrations of photosynthetic pigments and similar photosynthetic activity. Mahdavi et al. [36] and Wang et al. [37] attributed the difficulty they encountered when using satellite imagery to differentiate between vegetation types to wetlands having a high intra-species and low inter-species variability in reflectance.

\section{Conclusion}

The conservation of the Wakkerstroom wetland is critical due to its importance in providing a habitat for numerous bird and invertebrate species. It is necessary to understand the dynamics of the size of the wetland as well as changes in vegetation over time. Aereal photographs and Landsat 5 and 8 satellite images were used over the period 1938-2019. It was shown that the weland has increased in extent by $0.483 \mathrm{~km}^{2}$ from 1938 to 2009. The $P$. australis population density increased significantly over time $(\mathrm{r}=0.89)$, whereas the $T$. capensis population density had a strong negative correlation over time $(\mathrm{r}=-0.70)$. A strong negative relationship between $P$. australis and T. capensis existed $(\mathrm{r}=-0.88)$. This is worrying as $P$. australis is extremely aggressive and limits the types of habitats available for the birds and invertebrates. A carefully governed fire regime with occasional herbicide application would be the only management tool that would help limit the spread of $P$. australis. The fire should be used to introduce a mosaic of vegetation species and herbicide application to limit the regrowth of $P$. australis.

\section{Conflicts of Interest}

The authors declare no conflicts of interest regarding the publication of this paper.

\section{References}

[1] Zedler, J.B. and Kercher, S. (2005) Wetland Resources: Status, Trends, Ecosystem Services, and Restorability. Annual Review of Environmental Resources, 30, 39-74. https://doi.org/10.1146/annurev.energy.30.050504.144248

[2] Kotze, D.C., Breen, C.M. and Quinn, N. (1995) Wetland Losses in South Africa. In: Gowan, G.I., Ed., Wetlands of South Africa, Department of Environmental Affairs and Tourism, Durban, 263-272.

[3] Begg, G. (1986) The Wetlands of Natal (Part 1): An Overview of their Extent, Role, and Present Status. Natal Town and Regional Planning Commission Report No. 68, Pietermaritzburg, $114 \mathrm{p}$.

[4] Marnewick, M.D., Retief, E.F., Theron, N.T., Wright, D.R. and Anderson, T.A. (2015) Important Bird and Biodiversity Areas of South Africa. BirdLife South Africa, Johannesburg.

[5] De Steven, D. and Toner, M.M. (2004) Vegetation of Upper Coastal Plain Depression Wetlands: Environmental Templates and Wetland Dynamics within a Landscape Framework. Wetlands, 24, 23-42. https://doi.org/10.1672/0277-5212(2004)024[0023:VOUCPD]2.0.CO;2

[6] Joubert, R. and Ellery, W.N. (2013) Controls on the Formation of Wakkerstroom 
Vlei, Mpumalanga Province, South Africa. African Journal of Aquatic Science, 38, 135-151. https://doi.org/10.2989/16085914.2012.762897

[7] Tooth, S. and McCarthy, T.S. (2007) Wetlands in Drylands: Geomorphological and Sedimentological Characteristics, with Emphasis on Examples from Southern Africa. Progress in Physical Geography, 31, 3-41. https://doi.org/10.1177/0309133307073879

[8] Macfarlane, D., Kotze, D., Ellery, W., Walters, D., Koopman, V., Goodman, P. and Goge, M. (2009) WET-Health: A Technique for Rapidly Assessing Wetland Health. WRC Report TT 340/09, Accra.

[9] Joubert, R. (2009) The Origin and Dynamics of Wakkerstroom Vlei, Mpumalanga Province, South Africa. Doctoral Dissertation, University of KwaZulu-Natal, Westville.

[10] Best, R.G., Wehde, M.E. and Linder, R.L. (1981) Spectral Reflectance of Hydrophytes. Remote Sensing of Environment, 11, 27-35. https://doi.org/10.1016/0034-4257(81)90004-3

[11] Saltonstall, K. (2002) Cryptic Invasion by a Non-Native Genotype of the Common Reed, Phragmites australis, into North America. Proceedings of the National Academy of Sciences, 99, 2445-2449. https://doi.org/10.1073/pnas.032477999

[12] Struyf, E., Van Damme, S., Gribsholt, B., Bal, K., Beauchard, O., Middelburg, J.J. and Meire, P. (2007) Phragmites australis and Silica Cycling in Tidal Wetlands. Aquatic Botany, 87, 134-140. https://doi.org/10.1016/j.aquabot.2007.05.002

[13] Ollis, D.J., Snaddon, C.D. and Job, N.M. (2013) Classification System for Wetlands and Other Aquatic Ecosystems in South Africa. SANBI Biodiversity Series 22, South African National Biodiversity Institute, Pretoria.

[14] Zhang, Y., Lu, D., Yang, B., Sun, C. and Sun, M. (2011) Coastal Wetland Vegetation Classification with a Landsat Thematic Mapper Image. International Journal of Remote Sensing, 32, 545-561. https://doi.org/10.1080/01431160903475241

[15] Kotze, D. (2010) WET-Sustainable Use: A System for Assessing the Sustainability of Wetland Use. Water Research Commission, Pretoria.

[16] Halls, A. (1997) Wetlands, Biodiversity and the Ramsar Convention: The Role of the Convention on Wetlands in the Conservation and Wise Use of Biodiversity. Ramsar Convention Bureau, Gland.

[17] Bond, W.J. (1997) Fire. Vegetation of Southern Africa. Cambridge University Press, Cambridge, 421-446.

[18] Van Wilgen, B.W. (2009) The Evolution of Fire and Invasive Alien Plant Management Practices in Fynbos. South African Journal of Science, 105, 335-342. https://doi.org/10.4102/sajs.v105i9/10.106

[19] Ailstock, M.S., Norman, C.M. and Bushmann, P.J. (2001) Common Reed Phragmites australis. Control and Effects upon Biodiversity in Freshwater Nontidal Wetlands. Restoration Ecology, 9, 49-59. https://doi.org/10.1046/j.1526-100x.2001.009001049.x

[20] Kotze, D.C. (2013) The Effects of Fire on Wetland Structure and Functioning. African Journal of Aquatic Science, 38, 237-247. https://doi.org/10.2989/16085914.2013.828008

[21] Lötter, M.C., Mucina, L. and Witkowski, E.T.F. (2014) Classification of the Indigenous Forests of Mpumalanga Province, South Africa. South African Journal of Botany, 90, 37-51. https://doi.org/10.1016/j.sajb.2013.09.010

[22] Tooth, S., McCarthy, T., Rodnight, H., Keen-Zebert, A., Rowberry, M. and Brandt, 
D. (2014) Late Holocene Development of a Major Fluvial Discontinuity in Floodplain Wetlands of the Blood River, Eastern South Africa. Geomorphology, 205, 128-141. https://doi.org/10.1016/j.geomorph.2011.12.045

[23] R Core Team (2019) R: A Language and Environment for Statistical Computing. R Foundation for Statistical Computing, Vienna. https://www.R-project.org/

[24] Liaw, A. and Wiener, M. (2002) Classification and Regression by Random Forest. $R$ news, 2, 18-22.

[25] Tuominen, S. and Pekkarinen, A. (2004) Local Radiometric Correction of Digital Aerial Photographs for Multi-Source Forest Inventory. Remote Sensing of Environment, 89, 72-82. https://doi.org/10.1016/j.rse.2003.10.005

[26] Harvey, K.R. and Hill, G.J.E. (2001) Vegetation Mapping of a Tropical Freshwater Swamp in the Northern Territory, Australia: A Comparison of Aerial Photography, Landsat TM and SPOT Satellite Imagery. International Journal of Remote Sensing, 22, 2911-2925. https://doi.org/10.1080/01431160119174

[27] National Research Council (1995) Wetlands: Characteristics and Boundaries. National Academies Press, Washington DC.

[28] Dronova, I. (2015) Object-Based Image Analysis in Wetland Research: A Review. Remote Sensing, 7, 6380-6413. https://doi.org/10.3390/rs70506380

[29] Civco, D.L., Kennard, W.C. and Lefor, M.W. (1978) A Technique for Evaluating Inland Wetland Photointerpretation: The Cell Analytical Method (CAM). Photogrammetric Engineering and Remote Sensing, 44, 1045-1052.

[30] Davis, C.H. and Wang, X. (2003) Planimetric Accuracy of Ikonos 1 M Panchromatic Orthoimage Products and Their Utility for Local Government GIS Base Map Applications. International Journal of Remote Sensing, 24, 4267-4288. https://doi.org/10.1080/0143116031000070328

[31] Pal, M. (2005) Random Forest Classifier for Remote Sensing Classification. International Journal of Remote Sensing, 26, 217-222. https://doi.org/10.1080/01431160412331269698

[32] Whiteside, T. and Bartolo, R. (2015) Mapping Aquatic Vegetation in a Tropical Wetland Using High Spatial Resolution Multispectral Satellite Imagery. Remote Sensing, 7, 11664-11694. https://doi.org/10.3390/rs70911664

[33] Kirimi, F., Kuria, D. N., Thonfeld, F., Amler, E., Mubea, K., Misana, S., Menz, G. (2016) Influence of Vegetation Cover on the Oh Soil Moisture Retrieval Model: A Case Study of the Malina Wetland, Tanzania. Advances in Remote Sensing, 5, 28-42. https://doi.org/10.4236/ars.2016.51003

[34] Fang, C., Tao, Z., Gao, D. and Wu, H. (2016) Wetland Mapping and Wetland Temporal Dynamic Analysis in the Nanjishan Wetland Using Gaofen One Data. Annals of GIS, 22, 259-271. https://doi.org/10.1080/19475683.2016.1231719

[35] Wulder, M.A., White, J.C., Coops, N.C., Ortlepp, S., Warner, T.A., Nellis, M.D. and Foody, G.M. (2009) Remote Sensing for Studies of Vegetation Condition: Theory and Application. In: Warner, T.A., Nellis, M.D. and Foody, G.M., Eds., The SAGE Handbook of Remote Sensing, Sage Publishing, Thousand Oaks, 357-367. https://doi.org/10.4135/9780857021052.n25

[36] Mahdavi, S., Salehi, B., Granger, J., Amani, M., Brisco, B. and Huang, W. (2018) Remote Sensing for Wetland Classification: A Comprehensive Review. GIScience and Remote Sensing, 55, 623-658. https://doi.org/10.1080/15481603.2017.1419602

[37] Wang, C., Liu, H.Y., Zhang, Y. and Li, Y.F. (2014) Classification of land-Cover Types in Muddy Tidal Flat Wetlands Using Remote Sensing Data. Journal of Applied Remote Sensing, 7, Article ID: 073457. https://doi.org/10.1117/1.JRS.7.073457 